\title{
No upward trend in normalised windstorm losses in Europe: 1970-2008
}

\author{
J. I. Barredo \\ Institute for Environment and Sustainability, European Commission - Joint Research Centre, Ispra, Italy \\ Received: 4 August 2009 - Revised: 9 December 2009 - Accepted: 18 December 2009 - Published: 15 January 2010
}

\begin{abstract}
On 18 January 2007, windstorm Kyrill battered Europe with hurricane-force winds killing 47 people and causing 10 billion US $\$$ in damage. Kyrill poses several questions: is Kyrill an isolated or exceptional case? Have there been events costing as much in the past? This paper attempts to put Kyrill into an historical context by examining large historical windstorm event losses in Europe for the period 1970-2008 across 29 European countries. It asks the question what economic losses would these historical events cause if they were to recur under 2008 societal conditions? Loss data were sourced from reinsurance firms and augmented with historical reports, peer-reviewed articles and other ancillary sources. Following the same conceptual approach outlined in previous studies, the data were then adjusted for changes in population, wealth, and inflation at the country level and for inter-country price differences using purchasing power parity. The analyses reveal no trend in the normalised windstorm losses and confirm increasing disaster losses are driven by societal factors and increasing exposure.
\end{abstract}

\section{Introduction}

There is now clear evidence that societal changes and economic development are the main factors responsible for increasing losses from natural disasters in many jurisdictions. This has been shown to be the case for flood and hurricane losses in the US (Pielke Jr. and Landsea, 1998; Pielke Jr. and Downton, 2000; Pielke Jr. et al., 2008), tornadoes in the US (Brooks and Doswell, 2001), hurricane losses in the Caribbean region (Pielke Jr. et al., 2003), weather extremes in the US (Changnon et al., 2000; Changnon, 2003), flood losses in Europe (Barredo, 2009), tropical cyclones in India (Raghavan and Rajesh, 2003), and weather-driven disasters

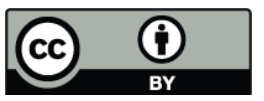

Correspondence to: J. I. Barredo (jose.barredo@jrc.ec.europa.eu) in Australia (Crompton and McAneney, 2008). All of these studies found no significant trends of losses after historical events were normalised to current conditions in order to account for demonstrably changing societal/demographic factors. In a similar vein, Schmidt et al. (2010) concluded that hurricane losses in the US were increasing as a consequence of socio-economic factors and natural variability; a "more likely than not" assessment was given for the current influence of anthropogenic forcings. Our present study sheds further light on the current role of anthropogenic vis-à-vis social economic factors in the case of windstorm losses in Europe.

This paper examines windstorm losses for the period 1970-2008 across 29 European countries including the member states of the European Union, Norway and Switzerland. By explicitly addressing the influence of socio-economic effects on the time-series of losses, it attempts to answer the question of what would be the magnitude of economic windstorm losses if events from the past were to recur under current societal conditions and whether, after adjusting for known changes in social conditions, a signal of anthropogenic climate change can be discerned.

Available data on losses from natural disasters in Europe is limited and suffers from a number of drawbacks (CEC, 2009). Limitations relate to poor quality, inhomogeneous data and records collected using a wide range of differing methods and different reasons. Currently, the most comprehensive natural disaster databases are held by insurance companies and are not publicly available (Bouwer et al., 2007). For this study, raw data was provided by the Natural Hazards Assessment Network (NATHAN) of the global reinsurance company Munich Re and complemented and improved with information from several other ancillary sources.

European windstorms are triggered by extratropical cyclones (ETCs). ETCs form in the transition zone between subtropical and polar climate zones. ETCs are mid-latitude weather systems that derive their energy from horizontal temperature contrast between cold, polar air masses and warm, 
subtropical air masses (Malmquist, 1999). The temperature contrasts between these air masses are greatest during winter, and so is the frequency and intensity of European windstorms. Maximum wind speeds can reach 140-200 km/h and, in extreme cases, up to $250 \mathrm{~km} / \mathrm{h}$ in exposed coastal locations. Wind fields may span up to $2000 \mathrm{~km}$ (Munich Re, 2008a) and thus affect several countries.

Although there is robust evidence of anthropogenic changes in the European climate (Alcamo et al., 2007; Rosenzweig et al., 2007; Trenberth et al., 2007), the question of whether there is an anthropogenic contribution to storm trends remains open. Several studies found no evidence of anthropogenic influence in Northeast Atlantic and Mediterranean European storm activity (Alexandersson et al., 1998, 2000; Bärring and von Storch, 2004; Alexander et al., 2005; Hegerl et al., 2007; Trenberth et al., 2007; Matulla et al., 2008; Bartholy et al., 2009). Other studies have identified changes in the storminess of the Northeast Atlantic region (McCabe et al., 2001; Weisse et al., 2005; Trigo, 2006; Wang et al., 2006, 2009; Leckebusch et al., 2008; Ulbrich et al., 2009). Evidence regarding small-scale wind weather phenomena, such as tornadoes, in Europe is mostly local and too scattered to draw general conclusions. In many European countries the number of reported tornado has increased considerably over the last decade, but the evidence point to this being a consequence of an increase in the reporting of weak tornadoes (Trenberth et al., 2007). The absence of a definitive answer to the anthropogenic contribution to storm trends suggests that a positive trend in the increase of windstorm losses may be attributed either to socio-economic changes or anthropogenic climate change and this is the focus of the present study.

The paper is organised in five sections. Section 2 analyses the available data and data sources. Section 3 describes the methodology used for normalising windstorm losses. Section 4 shows the results and trends of normalised losses. The last section examines the explanatory drivers of windstorm losses and assesses the results in the context of the available evidence of changes in storminess in the last decades. This section also considers the limitations of the method and the available data.

\section{Data}

This paper addresses direct economic losses from windstorms. Direct economic damage is the tangible economic loss associated with a windstorm's impact as determined after the event. Such losses result from the wind loading of property, vehicles, boats, scaffolding, cranes, forests, overhead line networks and agriculture. Indirect, secondary and tertiary (e.g. business interruption or losses due to interruption of power supply) and loss of life as well as longer-term macroeconomic effects such as the reductions in the tax base, while also important, lie outside the scope of this study.
Raw data on windstorm losses were obtained from the NATHAN database of Munich Re. NATHAN is a publicly accessible global database on natural disasters containing a global catalogue of significant natural-disaster losses and includes thematic information on major windstorm events such as casualties and direct economic losses. Records of disasters are based on what Munich Re defines "great natural catastrophes". This is in line with definitions used by the United Nations, where natural catastrophes are considered "great" if the affected region's ability to help itself is clearly overstretched and supra-regional or international assistance is required. This is the case when there are thousands of fatalities, hundreds of thousands of people are made homeless, or when the economic losses reach exceptional orders of magnitude. In NATHAN damage is the value of direct economic losses related to the disaster at the date at which the disaster occurred.

The information for this study was accessed in spring 2009. NATHAN provided information for 38 events registering economic losses between 1970 and 2008. The Munich $\operatorname{Re}(2002)$ report provided additional information on 13 events. Three missing events in Munich Re records were obtained from the studies of Lamb (1991) and Duglolecki et al. (1994). The resulting catalogue contains 54 events, a figure reasonably in line with the 55 "significant windstorms" identified in Europe by the Association of British Insurers between 1970 and 2005 (Climate Risk Management, 2005). Other ancillary sources of information from other reinsurers (e.g. Swiss Re), archives of on-line news channels, national weather services and various scientific papers also proved useful for verifying affected countries, amount of losses by country and by event, and date of occurrence. NATHAN reports losses in current US\$ and this currency has been used in this study.

Many sources of uncertainty affect the catalogue. Merging of data from different sources could lead to disparities due to different thresholds for inclusion. Nevertheless most events in the catalogue exceed a nominal (not adjusted for inflation) value of 100 million US\$. Another important source of uncertainty is the effect of improvements in data collection in recent decades that could induce biased trends (Berz, 2000; Barredo, 2009). To overcome these sources of uncertainty, we only consider losses produced by major disasters, i.e. those with normalised economic losses above a threshold of 1 billion US\$, a point to which we shall return in later discussion. This will guarantee a more homogeneous set of disaster records with a common threshold for inclusion. Furthermore there is usually better information for major disasters and can be investigated decades after their occurrence (Berz, 2000). 


\section{Methods}

Normalisation is used to account for changes in the socioeconomic factors known to contribute to increased natural disaster losses (Crompton and McAneney, 2008). The purpose of this exercise is to put all losses on a common basis that is reflective of the impact that historical events might produce if they were to recur under current (2008) societal conditions (Changnon et al., 1997; Pielke Jr. and Landsea, 1998; Pielke Jr. et al., 2008; Barredo, 2009). The conceptual approach follows that employed in previous studies in adjusting for changes in inflation, population and per capita wealth since the original event (Pielke Jr. and Landsea, 1998; Crompton and McAneney, 2008; Barredo, 2009). As information for the changes in wealth in exposed areas is rarely available, it is often necessary to use proxies in order to account for its influence (Changnon et al., 1997; Changnon and Changnon, 1998; Pielke Jr. and Landsea, 1998; Pielke Jr. and Downton, 2000; Changnon, 2003; Crompton and McAneney, 2008; Pielke Jr. et al., 2008; Barredo, 2009).

For example, Pielke Jr. and Landsea (1998) and Pielke Jr. et al. (2008) implemented a normalisation method for US hurricane damage by using factors to account for changes in population, inflation and real per capita wealth. Crompton and McAneney (2008) normalised losses from Australian meteorological hazards using two proxy factors, i.e. changes in the number and the average nominal value of dwellings over time; the effect of inflation was also calculated.

In a point of departure from previous authors, Barredo (2009) also introduced purchasing power parity (PPP) to eliminate price level differences across countries in his study of normalised flood losses at the level of continental Europe. PPP are defined as the rates of currency conversion that equalise the purchasing power of different currencies by eliminating the differences in price levels between countries. PPP are price relatives that reflect the ratio of the prices of the same good or service in different countries (OECD-EUROSTAT, 2006). Values expressed in PPP can be considered as standardised values. Timeseries data on PPP were obtained from the Total Economy Database of The Conference Board (2009).

The present study follows Barredo (2009) in adjusting the original data for inflation, inter-country price differences, population and per capita wealth at the country level. This study uses population and real GDP per capita in the country of the event as a measure of the changes in exposure over time. It is assumed that the overall trends of both factors at the country level are reflective of those of the impacted areas. Time-series data on GDP, population and inflation at country level were obtained from the Statistical Databases of United Nations Statistics Division and EUROSTAT. Time changes of real GDP per capita and population in the studied countries are given by way of example in Fig. 1 .

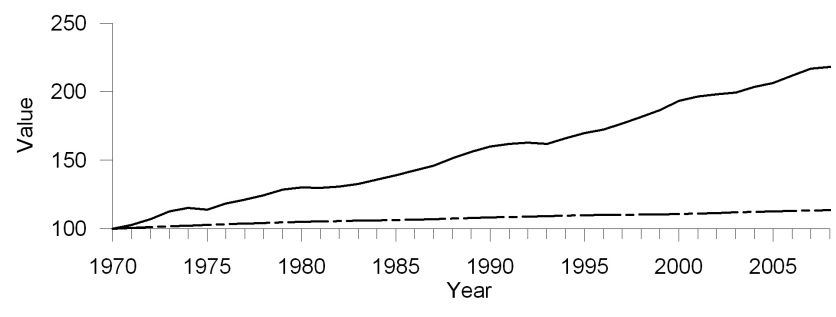

Fig. 1. Real GDP per capita (bold line) and population (dashed line) in the studied countries, 1970-2008 (1970 index value =100).

Table 1. Example of the normalisation method for the losses of storm 87J in France.

\begin{tabular}{ll}
\hline Original losses (1987) & $1600 \mathrm{~m}$ US\$ (nominal) \\
Inflation factor (1987-2008) & 1.86 \\
Population factor (1987-2008) & 1.12 \\
Wealth factor (1987-2008) & 1.38 \\
PPP factor (1987) & 0.83 \\
Normalised losses & $=3818 \mathrm{~m}$ int. US $\$$ of 2008 \\
\hline
\end{tabular}

The normalisation equation is defined as follows:

$L_{2008}=L_{i} \times I_{i j} \times \mathrm{PPP}_{i j} \times P_{i j} \times W_{i j}$

The equation converts nominal losses in the year of occurrence of the event $\left(L_{i}\right)$ to normalised losses in $2008\left(L_{2008}\right)$ expressed in international US\$ using PPP; $I_{i j}$ is the inflation factor to 2008 values for year $i$ in country $j$; $\operatorname{PPP}_{i j}$ is the purchasing power parity factor for year $i$ in country $j ; P_{i j}$ is the population factor defined as the ratio of the number of inhabitants in 2008 in country $j$ to the number in year $i ; W_{i j}$ is the wealth factor defined as the ratio of the real GDP per capita in 2008 in country $j$ to the value in year $i$.

For the sake of clarity we show by way of example the normalisation required to adjust the original losses resulting from storm 87J in France in 1987 (Table 1). The raw nominal damage was estimated at 1.6 billion US\$ (Munich Re, 2002). After adjusting for the various factors in Eq. (1), the normalised losses are estimated to be international 3.8 billion US\$ as of 2008. After calculating the normalised losses for each country affected by a storm, the losses are then aggregated for obtaining the total normalised losses for the event.

\section{Results}

Inspection of the number of damaging events included in the catalogue reveals that in the first half of the assessment, 1970-1989, there were 13 events, whereas in the second half, 1990-2008, there were 41 (Table 2). In Fig. 2 it is also evident an increase in the reporting of minor events in the last 
Table 2. Comparison between the number of damaging windstorms in the overall catalogue and the group of major disasters over time.

\begin{tabular}{ccc}
\hline & \multicolumn{2}{c}{ Number of events } \\
& $\begin{array}{c}\text { Overall } \\
\text { catalogue }\end{array}$ & $\begin{array}{c}\text { Major } \\
\text { events }\end{array}$ \\
\hline Overall period 1970-2008 & 54 & 25 \\
1st subperiod 1970-1989 & 13 & 11 \\
2nd subperiod 1990-2008 & 41 & 14 \\
Ratio of sub-periods & 3.2 & 1.3 \\
\hline
\end{tabular}

years of the assessment. The catalogue shows an increase in the number of events of $6.3 \%$ per year. Although studies of changes in storm frequency in the recent past show some differences (Ulbrich et al., 2009) an increase in severe storm frequency of the magnitude of that shown in the catalogue has not been evidenced. Studies for the North Atlantic European region show a modest increase in severe storms in recent decades (Hanson et al., 2004; Weisse et al., 2005; Trigo, 2006). For example, Trigo (2006) has found an increase in the most severe storms for the Atlantic North region in the order of $1.5 \%$ per year between the 1960 and 2000. A decreasing trend was found for the Northern Mediterranean region for the same period. Results of Weisse et al. (2005) are in line with Trigo (2006). They indicate that the number of severe storms increased near the exit of the European North Atlantic storm track, the most active region in Europe, by about $2 \%$ per year for the period 1958-2001. They also found a tendency towards decreasing storminess for areas south of $45^{\circ} \mathrm{N}$. Hence the increase of the number of events in the catalogue seems to be outside the bounds of natural variability or the effect of societal shifts and is, we suspect, likely a consequence of better accounting of natural disasters in the last decades. To minimise this bias, this study considers only major windstorms, i.e. those with losses larger than 1 billion in 2008 US $\$$ normalised values. Based on this criterion 25 out of 54 events originally included in the catalogue were classified as major disasters. The group of major disasters accounted for 11 and 14 events respectively in the two subperiods in Table 2. It is worth noting that $93 \%$ of the overall losses were produced by major events, representing only $46 \%$ of the overall number of events. In selecting just these major disasters, the effect of incompleteness is reduced considerably while retaining the most important losses observed during the study period. However, for the purpose of clarity we also assessed the trend of losses for the entire catalogue. Measured in 2008 US\$ normalised values, total windstorm losses from major events over the period 19702008 amounted to 141 billion, with an average annual loss of 3.6 billion.

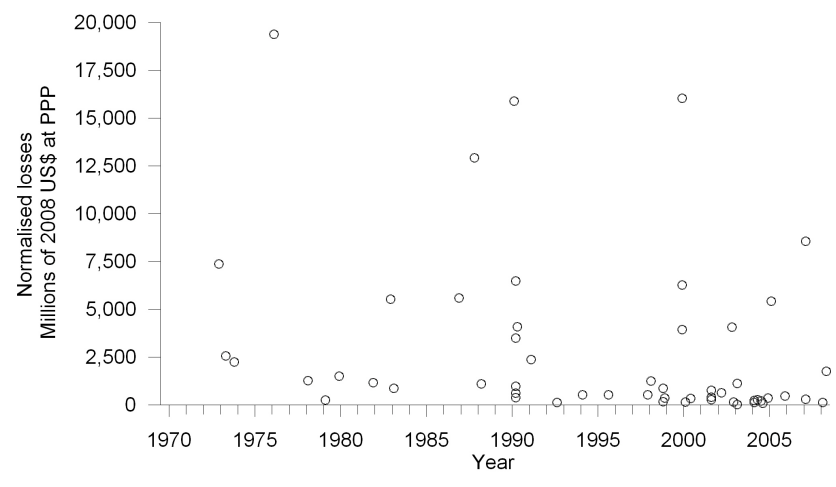

Fig. 2. Time-distribution of damaging windstorms included in the catalogue for Europe 1970-2008.

Figure 3 shows the annual distribution of the windstorm losses in constant US\$ of 2008 (after adjusted only for inflation). Note that because the raw losses are expressed in US\$ we used estimates of implicit price deflators for series in US\$ for each specific country. Information at country level on inflation rates for series measured in US\$ was obtained from the Statistical Databases of United Nations Statistics Division.

Figure 4 shows the normalised annual distribution of windstorm losses. In this figure losses are expressed in normalised 2008 US\$. 1990 registered the highest losses followed by 1999 and 1976. Between January and March 1990 a sequence of four devastating gales struck Europe producing losses close to 30 billion. In December 1999 another sequence of three severe windstorms produced normalised losses of 26 billion. And in 1976, Capella storm produced event losses of more than 19 billion. Figure 5 shows the 5 -year moving average of normalised losses. No trend is evident over time.

Appendix A includes the assessment of the entire catalogue. There are no significant differences between the results obtained from the group of major windstorms and the results from the entire catalogue. This is because most of the losses have been caused by major windstorm disasters. Despite it there are a number of small differences between the annual losses of Figs. 3 and 4 and the corresponding figures of the entire catalogue, A1 and A2. In many years the amount of losses is greater in the figures of the entire catalogue (e.g. 1990) and many other years registering no losses in the figures from major disasters report losses in the entire catalogue (e.g. 2000). Although the shape of the trend line is slightly different between Figs. 5 and A3 relevant differences are not evident. Figures of normalised losses from the entire catalogue (A2 and A3) show that no trend is evident over time. 


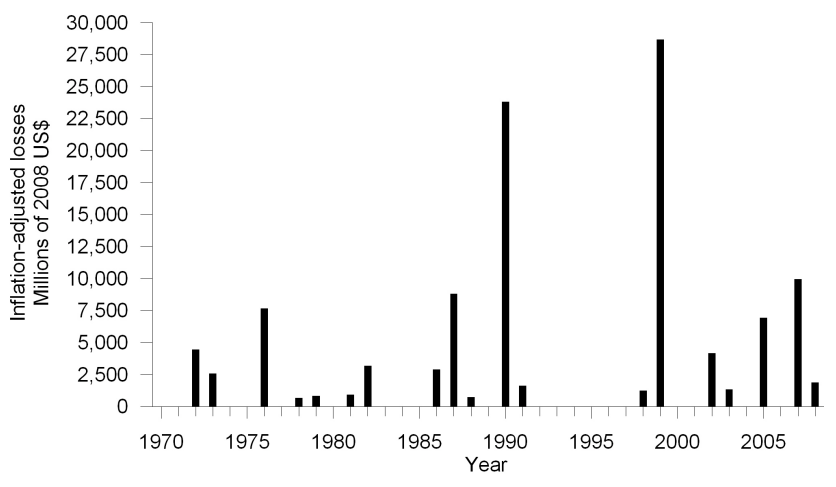

Fig. 3. Annual windstorm losses in Europe from major windstorm disasters (adjusted for inflation). The information in this figure must be viewed cautiously because it includes shifts due to societal changes over time.

\section{Discussion}

The most salient result is the absence of any positive trend in normalised windstorm losses in Europe. It appears that increasing standard of living, real per capita wealth and population in Europe are responsible for ever growing losses from windstorms. In other words, even without any anticipated impacts of anthropogenic climate change, windstorms losses will very likely continue to escalate purely as a consequence of the increase of societal and economic factors.

A number of recent studies suggest that storm activity over Europe has changed over the second half of the twentieth century (Ulbrich et al., 2009). Results of McCabe et al. (2001) and Wang et al. (2006) suggest a poleward shift of the storm track, with an increased storm activity over the North Atlantic. Other studies using reanalysis data (Weisse et al., 2005; Trigo, 2006; Leckebusch et al., 2008) have documented significant increases in the number or strength of severe storms in the Northeast Atlantic European region for the second part of the twentieth century. Nevertheless, results of Weisse et al. (2005) also suggest that between about 1990 and 1995 the increase has weakened over areas of the North Sea and has been replaced by a decrease in severe storm frequency. Besides a northward shift of the storm track and an increase in storminess in the second half of the twentieth century, station pressure data over the Atlantic-European sector show a modest increase in severe storms in recent decades. Additionally, decadal-scale fluctuations of similar magnitude have been observed earlier in the ninetieth and twentieth centuries (Alexandersson et al., 2000; Bärring and von Storch, 2004; Trenberth et al., 2007). Recently Matulla et al. (2008) reached similar conclusions over Northern and Central Europe using a dataset for 1880-2005. They found an increase in storminess from 1960s to the 1990s that ends at levels of storminess comparable to those of the beginning of the twentieth century. In line with these findings Alexander

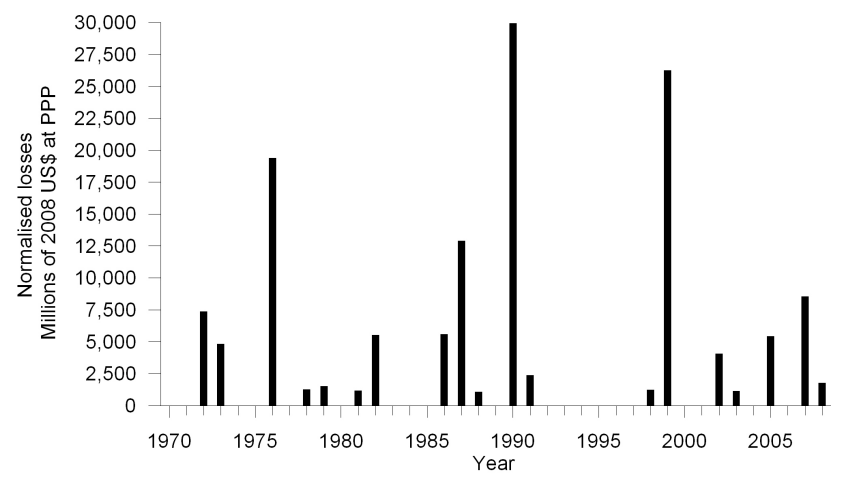

Fig. 4. Annual windstorm losses in Europe from major windstorm disasters normalised to 2008 values.

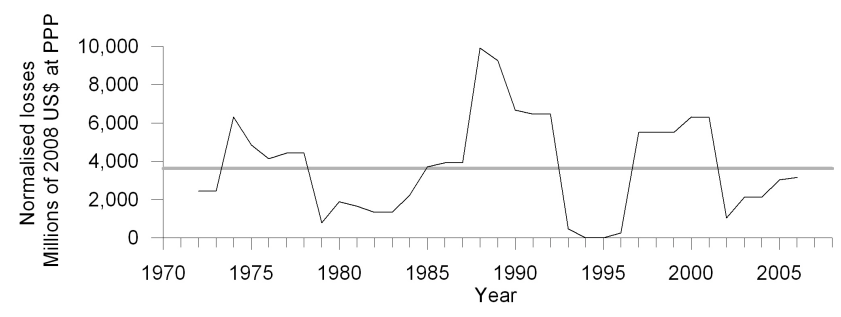

Fig. 5. 5-year moving average of annual windstorm losses in Europe from major windstorm disasters normalised to 2008 values. The grey line represents the average annual losses of the overall period.

et al. (2005) showed an increase in the number and intensity of severe storms over the southern UK since the 1950s. Wang et al. (2009) corroborates the findings of Alexandersson et al. $(1998,2000)$ in the annual metrics. However notable differences between winter and summer trends and an unprecedented storminess maximum in the early 1990s in winter in the North Sea area have been identified. To conclude, despite the changes on European storminess the evidence for an anthropogenic contribution to storm trends remains uncertain (Hegerl et al., 2007) and there is no evidence of an impact of anthropogenic climate change on the normalised windstorm losses.

Munich Re (2002) has also evaluated the effect of changes in exposed values in catastrophe regions in Europe. They converted the insured losses of a series of gales that occurred in 1990 to the losses they would have produced in 1999 after taking into account changes in insurance penetration and the average sum insured per policy. They found a striking increase of a factor of 1.8-2.0 for Western Europe in 9 years. In other words, the original EUR 8.5 billion losses for the storms Daria, Herta, Vivian and Wiebke would have resulted in around EUR 16 billion (in 1990 values) if they were to have occurred in 1999. In contrast our method has estimated an increase factor for storm $87 \mathrm{~J}$ in France of 1.5 in the 


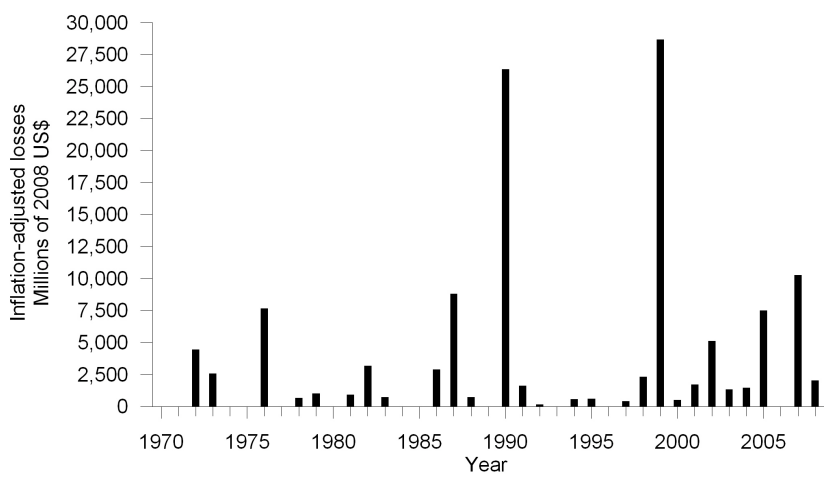

Fig. A1. Annual windstorm losses in Europe from windstorm disasters (adjusted for inflation). The information in this figure must be viewed cautiously because it includes shifts due to societal changes over time and the effect of improvements in disaster data collection in recent decades.

21-year period between 1987 and 2008, passing from 1.6 to 2.5 billion US $\$$ (1987 values) considering only the influence of changes in population and wealth, i.e. excluding inflation and the PPP factor. Thus the results of the Munich Re study confirm the relevance of societal drivers in explaining the increase of windstorm losses in Europe, and may indicate that the normalisation method implemented in this paper might be conservative and underestimate the losses from the past.

The presented metric of normalised losses has many advantages. It is simple, transparent and easy to communicate. Nevertheless, our results are subject to a number of constraints. Table 2 suggests that the raw dataset may contain biases due to better reporting in recent decades and that some records may be missing in the first decades of the assessment. However, comparison between the time series of Fig. A1 and that provided by Munich Re (2008b) reveals no relevant differences. We conclude that the catalogue implemented in this study represents a reasonably faithful record of windstorm disasters in Europe.

Changing building codes and construction standards may have an additional influence in determining the vulnerability of assets at risk from windstorms (Crompton and McAneney, 2008). The normalisation methodology used in this study, as is the case of most previous studies, ignores this factor. However, due to the predominance of massive (solid) construction of buildings in Europe, structural damage is usually the exception even when wind speeds are high (Munich Re, 2002). Moreover European windstorms have not the destructive potential of hurricanes and the losses usually involve damage to the outside shell of the buildings, i.e. roofs, façades, and windows. Although in recent years there has been a tendency towards buildings with outside attachments (pergolas, awnings, satellite antennae), that are potentially more prone to being damaged at high wind speeds than are the buildings themselves, we assume that their effect on the overall trend of losses is unlike to be large.

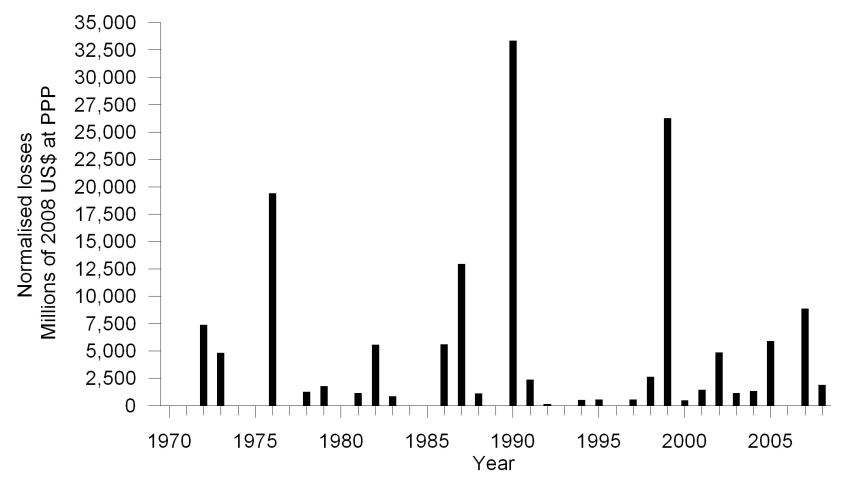

Fig. A2. Annual windstorm losses in Europe from windstorm disasters normalised to 2008 values. The information in this figure must be viewed cautiously because it includes shifts due to the effect of improvements in disaster data collection in recent decades.

Losses to forest have been a feature of several windstorms such as Kyrill. And timber losses have been growing in Europe since the 1950's (Munich Re, 2002). In Western Europe both the forest available for wood supply and the growing stock per hectare have increased since the 1950's. Accordingly the annual increment per unit area of forest has consistently increased about 64\% since 1950's (Gold, 2003; Lawson and Hemery, 2007). This increase explains reasonably well the increasing forest damage experienced in Europe in the last decades (Munich Re, 2002). Studies of European forest have also shown that the proportion of tall and hence more vulnerable trees has also increased.

The European Commission (CEC, 2009) claims that a better understanding of disasters is a pre-requisite for developing efficient disaster prevention policies. Policy making in the field of natural disasters should be supported by longterm accurate data and assessments. From this perspective the monitoring of losses from weather-driven disasters should become a priority if we are to better understand the evolution of impacts from disasters and the role that humaninduced climate change might play (Bouwer et al., 2007).

At the moment it seems clear that increasing disaster losses are overwhelmingly a consequence of changing societal factors. However questions concerning the linkage between weather-driven disaster losses and the future role of anthropogenic climate change will remain an important area of research (Höppe and Pielke Jr., 2006) and policy makers should not expect any unequivocal answer soon to such questions.

\section{Appendix A}

In this appendix we show the trend of losses calculated on the basis of data from the entire catalogue implemented in this study. Figures 3, 4 and 5 shown in the results chapter 


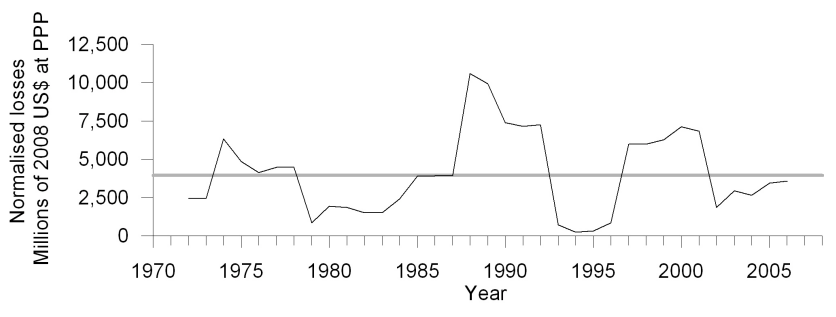

Fig. A3. 5-year moving average of annual windstorm losses in Europe from windstorm disasters normalised to 2008 values. The grey line represents the average annual losses of the overall period. The information in this figure must be viewed cautiously because it includes shifts due to the effect of improvements in disaster data collection in recent decades.

have been replicated here with data from the entire catalogue (see Figs. A1, A2 and A3). Figures of this appendix show that no trend is evident over time in normalised losses.

Acknowledgements. I would like to thank the anonymous referee and the editor for their helpful suggestions and John McAneney for his advice during the review of the manuscript. The views expressed are purely those of the writer and may not in any circumstance be regarded as stating an official position of the European Commission.

Edited by: U. Ulbrich

Reviewed by: J. McAneney and another anonymous referee

\section{References}

Alcamo, J., Moreno, J. M., Nováky, B., Bindi, M., Corobov, R., Devoy, R. J. N., Giannakopoulos, C., Martin, E., Olesen, J. E., and Shvidenko, A.: Europe. Climate Change 2007: Impacts, Adaptation and Vulnerability, in: Contribution of Working Group II to the Fourth Assessment Report of the Intergovernmental Panel on Climate Change, edited by: Parry, M. L., Canziani, O. F., Palutikof, J. P., van der Linden, P. J., and Hanson, C. E., Cambridge University Press, Cambridge, UK, 541-580, 2007.

Alexander, L. V., Tett, S. F. B., and Jonsson, T.: Recent observed changes in severe storms over the United Kingdom and Iceland, Geophys. Res. Lett., 32, L13704, doi:10.1029/2005GL022371, 2005.

Alexandersson, H., Schmith, T., Iden, K., and Tuomenvirta, H.: Long-term variations of the storm climate over NW Europe, The Global atmosphere and ocean system, 6, 97-120, 1998.

Alexandersson, H., Tuomenvirta, H., Schmith, T., and Iden, K.: Trends of storms in NW Europe derived from an updated pressure data set, Climate Res., 14, 71-73, 2000.

Barredo, J. I.: Normalised flood losses in Europe: 1970-2006, Nat. Hazards Earth Syst. Sci., 9, 97-104, 2009, http://www.nat-hazards-earth-syst-sci.net/9/97/2009/.

Bärring, L., and von Storch, H.: Scandinavian storminess since about 1800, Geophys. Res. Lett., 31, L20202, doi:10.1029/2004GL020441, 2004.
Bartholy, J., Pongrácz, R., and Pattantyús-Ábrahám, M.: Analyzing the genesis, intensity, and tracks of western Mediterranean cyclones, Theor. Appl. Climatol., 96, 133-144, 2009.

Berz, G.: Flood disasters: lessons from the past-worries for the future, P. I. Civil Eng.-Water, 142, 3-8, 2000.

Bouwer, L. M., Crompton, R. P., Faust, E., Hoppe, P., and Pielke Jr., R. A.: Disaster Management: Confronting Disaster Losses, Science, 318, p. 753, 2007.

Brooks, H. E. and Doswell, C. A.: Normalized Damage from Major Tornadoes in the United States: 1890-1999, Weather Forecast., 16, 168-176, 2001.

CEC: COM(2009)82 final: A Community approach on the prevention of natural and man-made disasters, Commission of the European Communities, Brussels, 23 February 2009.

Changnon, D. and Changnon, S. A.: Evaluation of Weather Catastrophe Data for Use in Climate Change Investigations, Climatic Change, 38, 435-445, 1998.

Changnon, S. A., Changnon, D., Fosse, E. R., Hoganson, D. C., Roth, R. J., and Totsch, J. M.: Effects of Recent Weather Extremes on the Insurance Industry: Major Implications for the Atmospheric Sciences, B. Am. Meteorol. Soc., 78, 425-435, 1997.

Changnon, S. A., Pielke, R. A., Changnon, D., Sylves, R. T., and Pulwarty, R.: Human Factors Explain the Increased Losses from Weather and Climate Extremes, B. Am. Meteorol. Soc., 81, 437442, 2000.

Changnon, S. A.: Shifting Economic Impacts from Weather Extremes in the United States: A Result of Societal Changes, Not Global Warming, Nat. Hazards, 29, 273-290, 2003.

Climate Risk Management: Financial risks of climate change Technical annexes, Association of British Insurers, London, UK, 39 pp., 2005.

Crompton, R. P. and McAneney, K. J.: Normalised Australian insured losses from meteorological hazards: 1967-2006, Environ. Sci. Policy, 11, 371-378, 2008.

Dlugolecki, A., Clement, D., Elvy, C., Kirby, G., Palutikof, J., Salthouse, R., Toomer, C., Turner, S., and Witt, D.: The impact of changing weather patterns on property insurance, The Chartered Insurance Institute Society of Fellows Study Group, London, QAR201, 73 pp., 1994.

Gold, S.: The development of European forest resources, 1950 to 2000 - A study implemented in the framework of the European Forest Sector Outlook Study (EFSOS), Food and Agriculture Organization of the United Nations (FAO), Geneva, Geneva timber and forest discussion papers, 101 pp., 2003.

Hanson, C. E., Palutikof, J. P., and Davies, T. D.: Objective cyclone climatologies of the North Atlantic - a comparison between the ECMWF and NCEP Reanalyses, Clim. Dynam., 22, 757-769, 2004.

Hegerl, G. C., Zwiers, F. W., Braconnot, P., Gillett, N. P., Luo, Y., Marengo Orsini, J. A., Nicholls, J., Penner, J. E., and Stott, P. A.: Understanding and Attributing Climate Change, in: Climate Change 2007: The Physical Science Basis. Contribution of Working Group I to the Fourth Assessment Report of the Intergovernmental Panel on Climate Change, edited by: Solomon, S., Qin, D., Manning, M., Chen, Z., Marquis, M., Averyt, K. B., Tignor, M., and Miller, H. L., Cambridge University Press, Cambridge, UK, 663-745, 2007.

Höppe, P. and Pielke Jr., R. A.: Workshop on Climate Change and Disaster Losses: Understanding and Attributing Trends and 
Projections, Hohenkammer, Germany, 266 pp., 2006.

Lamb, H.: Historic Storms of the North Sea, British Isles and Northwest Europe, Cambridge University Press, Cambridge, 204 pp., 1991.

Lawson, G. and Hemery, G. E.: World timber trade and implementing sustainable forest management in the United Kingdom - A report to the Woodland Policy Group, Land Use Policy Group - The UK statutory conservation, contryside and environment agencies, City Road, Peterborough, 85 pp., 2007.

Leckebusch, G. C., Renggli, D., and Ulbrich, U.: Development and application of an objective storm severity measure for the Northeast Atlantic region, Meteorol.e Z., 17, 575-587, 2008.

Malmquist, D. L.: European Windstorms and the North Atlantic Oscillation: Impacts, Characteristics, and Predictability - A Position Paper based on the proceedings of the Risk Prediction Initiative Workshop on European Winter Storms and the North Atlantic Oscillation, Risk Prediction Initiative, Hamilton, Bermuda, RPI Series No. 2, 21 pp., 1999.

Matulla, C., Schöner, W., Alexandersson, H., von Storch, H., and Wang, X.: European storminess: late nineteenth century to present, Clim. Dynam., 31, 125-130, 2008.

McCabe, G. J., Clark, M. P., and Serreze, M. C.: Trends in Northern Hemisphere Surface Cyclone Frequency and Intensity, J. Climate, 14, 2763-2768, 2001.

Munich Re: Winter storms in Europe (II) - Analysis of 1999 Losses and Loss Potentials, Munich Re, Munich, 72 pp., 2002.

Munich Re: Special feature issue - Risk factor of air, Munich Re, Munich, Losses and loss prevention, 1/2008, 57 pp., 2008a.

Munich Re: Highs and lows - Weather risks in central Europe, $\mathrm{Mu}$ nich Re, Munich, Knowledge series, 56 pp., $2008 \mathrm{~b}$.

OECD-EUROSTAT: EUROSTAT-OECD Methodological Manual on Purchasing Power Parities, OECD, Paris, Statistics, 267 pp., 2006.

Pielke Jr., R. A. and Landsea, C. W.: Normalized Hurricane Damages in the United States: 1925-95, Weather Forecast., 13, 621631,1998

Pielke Jr., R. A. and Downton, M. W.: Precipitation and Damaging Floods: Trends in the United States, 1932-97, J. Climate, 13, 3625-3637, 2000.

Pielke Jr., R. A., Rubiera, J., Landsea, C., Fernandez, M. L., and Klein, R.: Hurricane Vulnerability in Latin America and The Caribbean: Normalized Damage and Loss Potentials, Natural Hazards Review, 4, 101-114, 2003.

Pielke Jr., R. A., Gratz, J., Landsea, C. W., Collins, D., Saunders, M. A., and Musulin, R.: Normalized Hurricane Damage in the United States: 1900-2005, Natural Hazards Review, 31, 29-42, 2008.
Raghavan, S. and Rajesh, S.: Trends in Tropical Cyclone Impact: A Study in Andhra Pradesh, India, B. Am. Meteorol. Soc., 84, 635-644, 2003.

Rosenzweig, C., Casassa, G., Karoly, D. J., Imeson, A., Liu, C., Menzel, A., Rawlins, S., Root, T. L., Seguin, B., and Tryjanowski, P.: Assessment of observed changes and responses in natural and managed systems, in: Climate Change 2007: Impacts, Adaptation and Vulnerability in: Contribution of Working Group II to the Fourth Assessment Report of the Intergovernmental Panel on Climate Change, edited by: Parry, M. L., Canziani, O. F., Palutikof, J. P., van der Linden, P. J., and Hanson, C. E., Cambridge University Press, Cambridge, UK, 79-131, 2007.

Schmidt, S., Kemfert, C., and Höppe, P.: The impact of socioeconomics and climate change on tropical cyclone losses in the USA, Regional Environmental Change, in press, 2010.

The Conference Board: Total Economy Database, The Conference Board, available aat: http://www.conference-board.org/ economics, 2009.

Trenberth, K. E., Jones, P. D., Ambenje, P., Bojariu, R., Easterling, D., Klein Tank, A., Parker, D., Rahimzadeh, F., Renwick, J. A., Rusticucci, M., Soden, B., and Zhai, P.: Observations: Surface and Atmospheric Climate Change, in: Climate Change 2007: The Physical Science Basis. Contribution of Working Group I to the Fourth Assessment Report of the Intergovernmental Panel on Climate Change, edited by: Solomon, S., Qin, D., Manning, M., Chen, Z., Marquis, M., Averyt, K. B., Tignor, M., and Miller, H. L., Cambridge University Press, Cambridge, UK, 235-336, 2007.

Trigo, I.: Climatology and interannual variability of storm-tracks in the Euro-Atlantic sector: a comparison between ERA-40 and NCEP/NCAR reanalyses, Clim. Dynam., 26, 127-143, 2006.

Ulbrich, U., Leckebusch, G., and Pinto, J.: Extra-tropical cyclones in the present and future climate: a review, Theor. Appl. Climatol., 96, 117-131, 2009.

Wang, X., Zwiers, F., Swail, V., and Feng, Y.: Trends and variability of storminess in the Northeast Atlantic region, 1874-2007, Clim. Dynam., 33(7-8), 1179-1195, 2009.

Wang, X. L., Swail, V. R., and Zwiers, F. W.: Climatology and Changes of Extratropical Cyclone Activity: Comparison of ERA-40 with NCEP-NCAR Reanalysis for 1958-2001, J. Climate, 19, 3145-3166, 2006.

Weisse, R., von Storch, H., and Feser, F.: Northeast Atlantic and North Sea Storminess as Simulated by a Regional Climate Model during 1958-2001 and Comparison with Observations, J. Climate, 18, 465-479, 2005. 